\title{
……
}

RESEARCH AND EDUCATION

\section{Influence of adding nanoparticles on the hardness, tear strength, and permanent deformation of facial silicone subjected to accelerated aging}

\author{
Adhara S. Nobrega, DDS, ${ }^{a}$ Agda M. Andreotti, DDS, ${ }^{\mathrm{b}}$ Amália Moreno, DDS, ${ }^{\mathrm{c}}$ \\ Mário A. C. Sinhoreti, DDS, ${ }^{d}$ Daniela M. dos Santos, DDS, ${ }^{e}$ and Marcelo C. Goiato, DDS ${ }^{f}$
}

Maxillofacial prostheses, beyond protecting areas containing tissues that are exposed and bloody because of surgical resections, traumas, tumors, or congenital problems represent a noninvasive and risk-free treatment for esthetic recovery. They especially help improve self-esteem and quality of life and reintegration of the patient into society. ${ }^{1-3}$

Silicone is the material used most in the fabrication of maxillofacial prostheses ${ }^{4-7}$ because its flexibility provides the patient with both wellbeing and comfort. It also possesses a texture similar to that of human skin, is stable when exposed to heat, and repels water, blood, and organic materials, thereby eliminating bacterial colonization. ${ }^{1,8,9}$ In addition, it is resistant to the action of cleaning and is the best commercially available material. ${ }^{1,8,9}$

However, silicone is limited in that early material deterioration may occur. For example, it may exhibit modified texture, poorly fitting edges because of shape Dent 2016;116:623-629)

\begin{abstract}
Statement of problem. The efficiency of adding nanoparticles to silicone protection has proven to prevent color degradation. However, reports of other physical property changes in facial silicone are scarce.

Purpose. The purpose of this in vitro study was to evaluate the influence of adding nanoparticles on the hardness, tear strength, and permanent deformation of a facial silicone.

Material and methods. Specimens were made for each test, with 140 for the hardness test, 140 for the permanent deformation test, but 280 for the rupture test. This higher number was due to the fact that the first 140 specimens were ruptured and unusable after the initial reading. $\mathrm{ZnO}, \mathrm{BaSO}_{4}$, and $\mathrm{TiO}_{2}$ nanoparticles at concentrations of $1 \%$ and $2 \%$ of silicone were used, as well as specimens without nanoparticles that consisted of only oil paint and of only silicone. Outcomes were measured before and after 1008 hours of accelerated aging. Data were analyzed by nested analysis of variance (ANOVA) and Tukey honest significant differences test $(\alpha=.05)$.
\end{abstract}

Results. Results showed that the presence of nanoparticles influenced the properties of the assessed groups. The nanoparticles decreased hardness values. The highest values of tear strength were observed for the groups with addition of $\mathrm{BaSO}_{4}$. The $1 \% \mathrm{ZnO}$ group without oil paint showed the lowest values of permanent deformation.

Conclusions. Based on the findings of this in vitro study, the use of $\mathrm{ZnO}$ nanoparticles is recommended, since they did not negatively affect the properties of the materials evaluated. (J Prosthet

changes, reduced tear strength, and material discoloration after only 3 months of use. ${ }^{9-12}$ These changes are directly related to patient care during handling and hygiene and the type of exposure that the prosthesis undergoes (air pollution, ultraviolet [UV] rays, temperature fluctuations). ${ }^{9-1}$

\footnotetext{
Supported by Sao Paulo Research Foundation Master Scholarship 2012/05270-3, Sao Paulo, Brazil. Presented at the 93rd Annual Meeting of the International Association for Dental Research, Boston, Mass, March 2015.

${ }^{a}$ Doctoral student, Department of Dental Materials and Prosthodontics, Aracatuba Dental School, Sao Paulo State University, Sao Paulo, Brazil.

boctoral student, Department of Dental Materials and Prosthodontics, Aracatuba Dental School, Sao Paulo State University, Sao Paulo, Brazil.

${ }^{c}$ Adjunct Professor, Department of Oral Surgery, Pathology and Dental Clinical, School of Dentistry, Minas Gerais Federal University, Minas Gerais, Brazil.

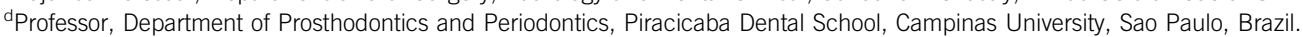

eProfessor, Department of Dental Materials and Prosthodontics, Aracatuba Dental School, Sao Paulo State University, Sao Paulo, Brazil.

fProfessor, Department of Dental Materials and Prosthodontics, Aracatuba Dental School, Sao Paulo State University, Sao Paulo, Brazil.
} 


\section{Clinical Implications}

Nanoparticles are used to prevent silicone discoloration. Therefore, the use of $\mathrm{ZnO}$ nanoparticles may be a viable method of avoiding facial silicone discoloration, as they do not negatively affect the material hardness, tear strength, or permanent deformation.

Different methods have been tested to prevent the intrinsic and extrinsic discoloration of the material. One of these methods is addition of nanoparticles, which are opacifiers such as zinc oxide $(\mathrm{ZnO})$, barium sulfate $\left(\mathrm{BaSO}_{4}\right)$, and titanium dioxide $\left(\mathrm{TiO}_{2}\right){ }^{3}$. They are used in the manufacture of sunscreens to protect human skin against UV rays because they have a high refractive index. ${ }^{14,15}$ As the nanoparticles are smaller than the UV light wavelength, their electrons vibrate when they hit by such radiation, thereby dissipating one portion of the light while absorbing another. Thus, the smaller the nanoparticles, the better the shielding against solar radiation. ${ }^{16}$

Several studies have confirmed the effectiveness of nanoparticles in protecting silicone against color deterioration, since nanoparticles block the ultraviolet rays and so increase its durability. $3,5,6,16-22$ However, to increase material durability, other important properties should also be evaluated. ${ }^{23,24}$ The hardness of silicone determines its flexibility and enables the prosthesis to mimic the skin texture as closely as possible, promoting greater comfort for the patient. ${ }^{10,25-28}$ Its tear strength should be adequate to allow the edge of the prosthesis to have good marginal adaptation ${ }^{10,28,29}$ and endurance during its removal, even though it is very thin. ${ }^{23,30}$ Its elastic recovery ability, evaluated through the permanent deformation test, ensures a good fit of the prosthesis without the material changing its shape when subjected to different types of forces during its daily handling. 31,32

Although some studies ${ }^{33-36}$ assert that nanoparticles may provide benefits, including the improvement of the physical properties of polymers, the number of published studies is scarce related to changes in hardness, tear strength, and permanent deformation when nanoparticles are added to facial silicone. The purpose of this in vitro study was to evaluate the influence of the addition of nanoparticles on the hardness, tear strength, and permanent deformation of a facial silicone under the influence of accelerated aging. The null hypothesis was that the addition of nanoparticles and accelerated aging would not influence these properties of the studied silicone.

\section{MATERIAL AND METHODS}

For specimen fabrication, a facial silicone (Silastic MDX44210; Dow Corning Corp Medical Products), 3 types of
Table 1. Material used for specimen fabrication

\begin{tabular}{ll}
\hline Trade or Generic Name & \multicolumn{1}{c}{ Manufacturer } \\
\hline Silicone silastic MDX4-4210 & Dow Corning Corp Medical Products \\
\hline Zinc oxide & Apothicário \\
\hline Barium sulfate & Apothicário \\
\hline Titanium dioxide & Apothicário \\
\hline Oil paint & Acrilex \\
\hline
\end{tabular}

nanoparticles, and a brown oil paint (Table 1) were selected. A total of 560 facial silicone specimens were fabricated. Only 280 specimens were used in the hardness and permanent deformation tests ( 140 for each test). The other 280 specimens were prepared for the tear strength test, with half for the initial test (ruptured and lost) and the other half for the final test. For each test, the specimens were divided into 14 groups $(n=10)$ according to nanoparticle type and concentration. Ten specimens were made for each nanoparticle type $\left(\mathrm{ZnO}, \mathrm{BaSO}_{4}\right.$, or $\left.\mathrm{TiO}_{2}\right)$. Thirty specimens were made for each nanoparticle concentration (1\% or $2 \%) .{ }^{16}$ Sixty specimens were made with pigmented silicone with oil paint and 60 without pigmentation. Twenty specimens were created without nanoparticles for each test; 10 with oil paint and 10 without oil paint.

The silicone and pigments were weighed on a digital precision scale (Adventurer; Ohaus Corp), and the nanoparticles ${ }^{16}$ and oil paint were added according to the proposed group. ${ }^{5,36}$

For specimen fabrication for the hardness test, a metal matrix was obtained containing 10 circular compartments with dimensions of $30 \times 2 \mathrm{~mm}$ in its interior. ${ }^{26,37}$ For the tear strength test, a metal matrix was obtained containing 6 compartments with dimensions of $75 \times 25 \times 0.5 \mathrm{~mm}$. $^{38}$ For the permanent deformation test, a metal matrix with 10 cylindrical compartments with dimensions of $20 \times 12.5$ mm was used. ${ }^{3}$

The silicone was handled according to the manufacturer's specifications at a controlled temperature of 23 $\pm 2^{\circ} \mathrm{C}$. Each nanoparticle and/or pigment was mixed with silicone on a glass slab with a stainless steel spatula until a homogeneous mass was obtained. The average diameter of each nanoparticle was $390 \mathrm{~nm}$ for $\mathrm{ZnO}, 250 \mathrm{~nm}$ for $\mathrm{TiO}_{2}$, and $670 \mathrm{~nm}$ for $\mathrm{BaSO}_{4}$ (Figs. 1-3). The silicone mixture was then inserted into the matrix, its surface was flattened with a spatula, and its thickness was standardized. The matrix was placed in a polymerization device with $0.96 \mathrm{kPa}$ of pressure to avoid bubble formation in the silicone. Specimens remained confined within the matrix under controlled temperature with the surface exposed for 72 hours to complete polymerization of the material with release of the byproduct (formaldehyde). After silicone polymerization, each specimen was carefully separated from the metallic matrix.

The hardness test evaluation (Shore A) was performed using a digital durometer (GDS 709; Teclock) according to American Society for Testing Materials 


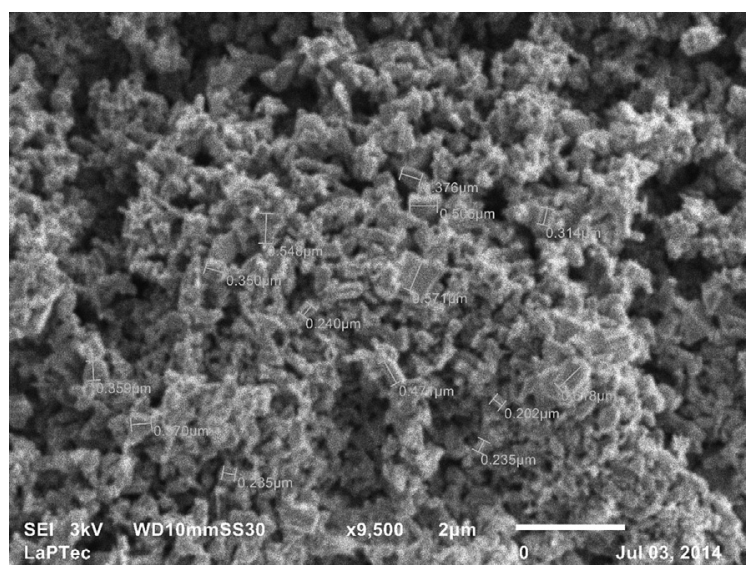

Figure 1. Scanning electron microscopy analysis of zinc oxide nanoparticles with medium diameter of $390 \mathrm{~nm}$ (original magnification $\times 9500)$.

(ASTM) standard D-2240. ${ }^{40-43}$ This method is based on needle penetration of the material surface under a constant load of $10 \mathrm{~N}$.

The tear strength test was performed according to the standards outlined by ASTM standard D 1938-67..$^{38-44}$ In order to facilitate the tension distribution on the specimen during the test, 3 points were marked with a scalpel. A spot was marked between the larger edges, centered and $50 \mathrm{~mm}$ distant from the first edge, while the other 2 points were marked $25 \mathrm{~mm}$ and $15 \mathrm{~mm}$ from this edge.

The larger edges of the specimen were secured in a universal testing machine (EMIC; São José dos Pinhais). The machine was operated at a constant speed of $25 \mathrm{~mm} / \mathrm{min}$ and load of $166.7 \mathrm{~N}$. Maximum resistance values were recorded. Half of the specimens from each group were tested at this time, whereas the other half was tested after accelerated aging.

The permanent deformation test was performed according to International Standards Organization (ISO) specification 4823:2000. ${ }^{39}$ Deformation measurements were performed through a zeroed dial indicator. This device has an analog marker graduated in increments of $0.01 \mathrm{~mm}$. The specimens were subjected to a compressive load of $9.8 \mathrm{~N}$ applied for 1 minute, enabling the reading of the initial deformation of each specimen (A). After charge removal and specimen stabilization, a re-read was performed, indicating the elastic recovery rate (B). The difference between the $\mathrm{A}$ and $\mathrm{B}$ values divided by the original length of the specimen and multiplied by 100 was regarded as the permanent deformation of the specimen. ${ }^{44}$

After the initial readings of the test result, the specimens were subjected to the accelerated aging test (aging chamber for nonmetallic specimens with UVB/condensation; Equilam) ${ }^{45}$ and subjected to alternating periods of UV light and distilled water condensation saturated with

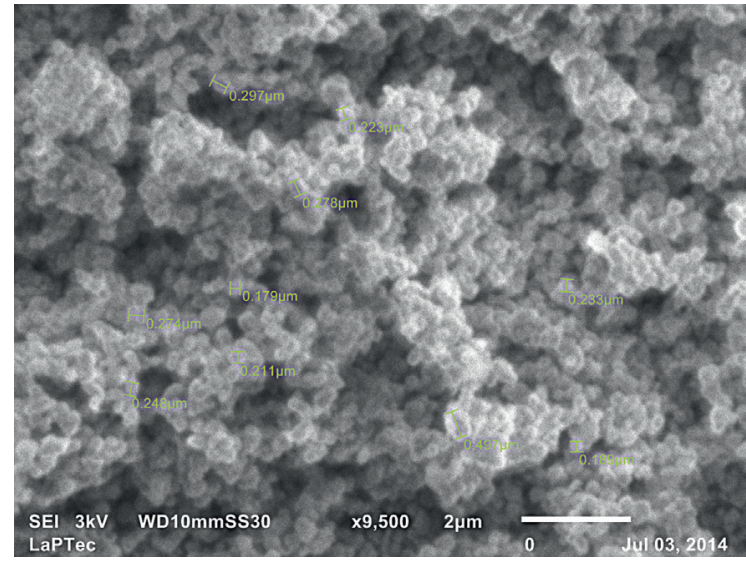

Figure 2. Scanning electron microscopy analysis of barium sulfate nanoparticles with medium diameter of $670 \mathrm{~nm}$ (original magnification $\times 9500)$.

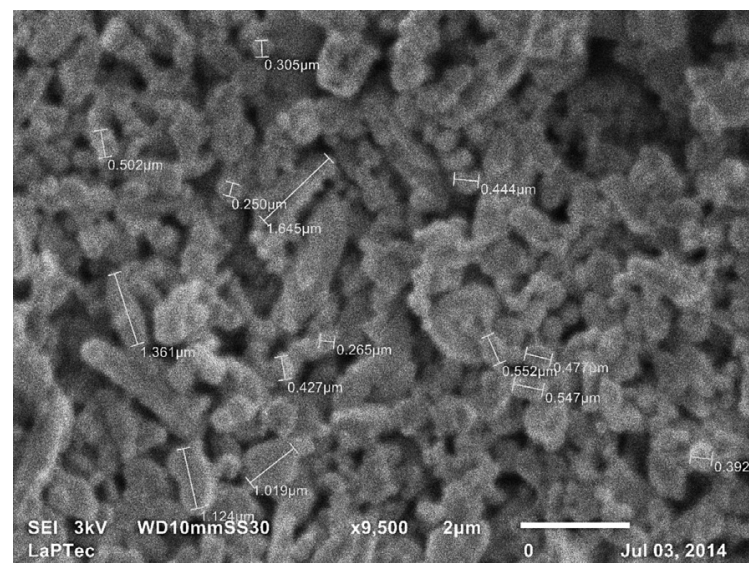

Figure 3. Scanning electron microscopy analysis of titanium dioxide nanoparticles with medium diameter of $250 \mathrm{~nm}$ (original magnification $\times 9500)$.

oxygen under conditions of heat and 100\% humidity. Each aging period was carried out for 12 hours. Silicone was exposed to UV light at $60 \pm 3^{\circ} \mathrm{C}$ for the first 8 hours. In the remaining 4 hours, the water condensation procedure occurred without light at $45 \pm 3^{\circ} \mathrm{C}$. This test was performed for 1008 hours, $5,6,8,9,11,17,26$ simulating the deterioration caused by rain, moisture, and the UV rays of the sun. The tear strength specimens were ruptured and lost after the initial reading. Therefore, their duplicates were aged for this test.

Data were evaluated using 4-way nested ANOVA. Nested effects can be used when constraints prevent crossing every level of 1 factor with every level of the other factor. ${ }^{35}$ ANOVA was used to evaluate the effects of oil paint treatment, nanoparticle concentration, nanoparticle type, period (before and after accelerated aging) on the hardness, tear strength, and permanent deformation values of facial silicone. The ANOVA was performed by nesting the nanoparticle factor to 
Table 2. Mean ( \pm SD) hardness (Shore A) for all groups in initial and final periods

\begin{tabular}{|c|c|c|}
\hline \multirow{2}{*}{$\begin{array}{l}\text { Oil Paint/ } \\
\text { Concentration/Nanoparticle }\end{array}$} & \multicolumn{2}{|c|}{ Period } \\
\hline & Initial & Final \\
\hline \multicolumn{3}{|l|}{ No } \\
\hline- & $27.23( \pm 1.82)^{\mathrm{Aa}}$ & $31.93( \pm 1.86)^{\mathrm{Ab}}$ \\
\hline \multicolumn{3}{|l|}{$1 \%$} \\
\hline $\mathrm{ZnO}$ & $23.57( \pm 1.01)^{\mathrm{Ba}}$ & $28.43( \pm 1.28)^{\mathrm{BCb}}$ \\
\hline $\mathrm{BaSO}_{4}$ & $22.07( \pm 1.98)^{\mathrm{BCa}}$ & $28.47( \pm 1.84)^{\mathrm{BCb}}$ \\
\hline $\mathrm{TiO}_{2}$ & $18.23( \pm 2.07)^{\text {DEa }}$ & $23.80( \pm 0.94)^{\mathrm{DEb}}$ \\
\hline \multicolumn{3}{|l|}{$2 \%$} \\
\hline $\mathrm{ZnO}$ & $25.97( \pm 0.74)^{\mathrm{Aba}}$ & $29.33( \pm 1.04)^{\mathrm{Bb}}$ \\
\hline $\mathrm{BaSO}_{4}$ & $25.50( \pm 1.51)^{\mathrm{Aba}}$ & $28.80( \pm 0.98)^{\mathrm{Bb}}$ \\
\hline $\mathrm{TiO}_{2}$ & $25.13( \pm 2.15)^{\mathrm{Aba}}$ & $27.63( \pm 1.10)^{\mathrm{BCa}}$ \\
\hline \multicolumn{3}{|l|}{ Yes } \\
\hline- & $26.70( \pm 1.22)^{\mathrm{Aa}}$ & $29.80( \pm 1.01)^{\mathrm{ABb}}$ \\
\hline \multicolumn{3}{|l|}{$1 \%$} \\
\hline $\mathrm{ZnO}$ & $22.10( \pm 1.50)^{\mathrm{BCa}}$ & $28.93( \pm 1.64)^{\mathrm{Bb}}$ \\
\hline $\mathrm{BaSO}_{4}$ & $19.80( \pm 1.32)^{\mathrm{Ca}}$ & $25.97( \pm 1.02)^{\mathrm{Eb}}$ \\
\hline $\mathrm{TiO}_{2}$ & $18.90( \pm 2.99)^{\text {DEa }}$ & $21.47( \pm 1.11)^{\mathrm{Db}}$ \\
\hline \multicolumn{3}{|l|}{$2 \%$} \\
\hline $\mathrm{ZnO}$ & $25.63( \pm 1.99)^{\mathrm{Aba}}$ & $29.90( \pm 1.00)^{\mathrm{ABb}}$ \\
\hline $\mathrm{BaSO}_{4}$ & $24.80( \pm 1.26)^{\mathrm{Aba}}$ & $28.67( \pm 1.78)^{\mathrm{Bb}}$ \\
\hline $\mathrm{TiO}_{2}$ & $19.13( \pm 1.60)^{\mathrm{DEa}}$ & $22.27( \pm 0.86)^{\mathrm{Bb}}$ \\
\hline
\end{tabular}

Groups statistically different from each other by Tukey test $(P<.05)$ are indicated by different superscript uppercase letters (within column) and lowercase letters (within row).

the concentration factor because the levels of the nanoparticle factor were not the same for the levels of the concentration factor. Statistical software (Software R v.3.2.3.; The R Foundation) was used for descriptive and statistical analyses. If the ANOVA test showed a significant difference, then the Tukey HSD post hoc test was applied $(\alpha=.05)$.

\section{RESULTS}

Nanoparticle presence influenced hardness, tear strength, and permanent deformation (Tables 2-4). The ANOVA for hardness values showed statistically significant differences $(P=.012)$ in the interaction among the factors oil paint, nanoparticle (concentration), and period (Supplemental Table 1).

In the initial period, the presence of nanoparticles decreased hardness values (Table 2). A statistically significant increase $(P<.001)$ in hardness values was verified after aging (final period), except for the $2 \% \mathrm{TiO}_{2}$ group without oil paint $(P=.080)$. However, even with this increase, the groups with the addition of $\mathrm{TiO}_{2}$ nanoparticles showed the lowest hardness values in the final period. The addition of oil paint did not influence the hardness values, except for the $2 \% \mathrm{TiO}_{2}$ group in the initial period.

Statistically significant differences $(P<.05)$ in tear strength were observed in the interaction between oil paint and nanoparticle (concentration); period and
Table 3. Average values of tear strength (MPa) for all groups, regardless of addition of oil paint

\begin{tabular}{clc}
\hline & \multicolumn{2}{c}{ Period } \\
\cline { 2 - 3 } Concentration/Nanoparticle & Initial & Final \\
\hline $1 \%$ & $1.89^{\mathrm{Aa}}$ & $2.46^{\mathrm{Ab}}$ \\
\hline $\mathrm{ZnO}$ & & \\
\hline $\mathrm{BaSO}_{4}$ & $1.92^{\mathrm{Aa}}$ & $2.30^{\mathrm{Aa}}$ \\
\hline $\mathrm{TiO}_{2}$ & $2.10^{\mathrm{Aa}}$ & $3.11^{\mathrm{Bb}}$ \\
\hline $2 \%$ & $1.83^{\mathrm{Aa}}$ & $2.39^{\mathrm{Ab}}$ \\
\hline $\mathrm{ZnO}$ & & \\
\hline $\mathrm{BaSO}_{4}$ & $2.32^{\mathrm{Aa}}$ & $2.39^{\mathrm{Aa}}$ \\
\hline $\mathrm{TiO}_{2}$ & $2.10^{\mathrm{Aa}}$ & $2.48^{\mathrm{Aa}}$ \\
\hline
\end{tabular}

Groups statistically different from each other by Tukey test $(P<.05)$ are indicated by different superscript uppercase letters (within column) and lowercase letters (within row).

Table 4. Mean percentages of permanent deformation for all groups, regardless of addition of oil paint

\begin{tabular}{lcc}
\hline & \multicolumn{2}{c}{ Period } \\
\cline { 2 - 3 } Concentration/Nanoparticle & Initial & Final \\
\hline $1 \%$ & $1.03^{\mathrm{ACa}}$ & $0.83^{\mathrm{Ab}}$ \\
\hline $\mathrm{ZnO}$ & & \\
\hline $\mathrm{BaSO}_{4}$ & $0.81^{\mathrm{DEa}}$ & $0.70^{\mathrm{Aa}}$ \\
\hline $\mathrm{TiO}_{2}$ & $1.13^{\mathrm{ABCa}}$ & $0.81^{\mathrm{Ab}}$ \\
\hline $2 \%$ & $0.98^{\mathrm{CEa}}$ & $0.69^{\mathrm{Ab}}$ \\
\hline $\mathrm{ZnO}$ & & \\
\hline $\mathrm{BaSO}_{4}$ & $0.91^{\mathrm{ACDa}}$ & $0.77^{\mathrm{Aa}}$ \\
\hline $\mathrm{TiO}_{2}$ & $1.24^{\mathrm{Ba}}$ & $0.86^{\mathrm{Ab}}$ \\
\hline
\end{tabular}

Groups statistically different from each other by Tukey test $(P<.05)$ are indicated by different superscript uppercase letters (within column) and lowercase letters (within row).

nanoparticle (concentration); and oil paint, concentration, and period factors (Supplemental Table 2). Higher values of tear strength after aging (final period) could be observed, with a statistically significant difference $(P<.05)$ for the groups with $1 \% \mathrm{BaSO}_{4}$ and $1 \% \mathrm{TiO}_{2}$ nanoparticle addition (Table 3). Moreover, the highest values of tear strength were observed for the groups with $\mathrm{BaSO}_{4}$ addition in the final period, with a statistically significant difference $(P=.01)$ in the group with $1 \%$ concentration. ANOVA for permanent deformation values exhibited statistically significant differences $(P<.05)$ in the interaction between period and concentration and between period and nanoparticle (concentration) (Supplemental Table 3).

In relation to permanent deformation, accelerated aging (final period) showed decreased values, except for the $2 \% \mathrm{TiO}_{2}$ group, which showed higher values with a statistically significant difference $(P<.05)$ compared with the other groups (Table 4). The $1 \% \mathrm{ZnO}$ group without oil paint showed the lowest values of permanent deformation, with a statistically significant difference $(P<.05)$ compared with the other groups without oil paint and compared with the $1 \% \mathrm{ZnO}$ group with oil paint (Table 5). 
Table 5. Mean percentages of permanent deformation for all groups, regardless of period

\begin{tabular}{clc}
\hline & \multicolumn{2}{c}{ Oil Paint } \\
\cline { 2 - 3 } Concentration/Nanoparticle & No & Yes \\
\hline & $0.89^{\mathrm{Aca}}$ & $0.98^{\mathrm{ABa}}$ \\
\hline $\mathrm{ZnO}$ & & \\
\hline $\mathrm{BaSO}_{4}$ & $0.65^{\mathrm{Ba}}$ & $0.86^{\mathrm{ABb}}$ \\
\hline $\mathrm{TiO} 2$ & $0.95^{\mathrm{Aca}}$ & $0.98^{\mathrm{ABa}}$ \\
\hline $2 \%$ & $0.84^{\mathrm{Aa}}$ & $0.83^{\mathrm{Aa}}$ \\
\hline $\mathrm{ZnO}$ & & $0.82^{\mathrm{Aa}}$ \\
\hline $\mathrm{BaSO}$ & & $1.04^{\mathrm{Ba}}$ \\
\hline $\mathrm{TiO}_{2}$ & $0.80^{\mathrm{Aa}}$ & $1.00^{\mathrm{ABa}}$ \\
\hline
\end{tabular}

Groups statistically different from each other by Tukey test $(P<.05)$ are indicated by different superscript uppercase letters (within column) and lowercase letters (within row).

\section{DISCUSSION}

The null hypothesis was rejected because the addition of nanoparticles and accelerated aging influenced the physical properties evaluated. The addition of nanoparticles in the initial period decreased the hardness values (Table 1). This may be due to nanoparticle incorporation into the silicone matrix, which may hinder the intertwining of the polymer chains, reducing the material polymerization rate. However, the hardness values increased after aging, independently of the addition of the nanoparticles. Several studies ${ }^{22,26,27,43}$ have indicated that accelerated aging increases the degree of polymerization of facial silicone, because this material polymerizes continuously. The greatest release of formaldehyde occurs in the first 72 hours. However, the release of the byproduct after this period continues indefinitely ${ }^{6,43}$ and could be related to the main changes in the structure of the silicone. ${ }^{30}$ Therefore, the nanoparticles decreased the hardness values, but they could not hinder the continuous polymerization degree of silicone.

When a polymer molecule absorbs UV light, this energy promotes instability in the molecular structure. The excess energy is transmitted by excitation from one molecule to another, allowing the first molecule to recover its stability. Therefore, affected groups may return to their original state by releasing energy in the form of longer wavelengths, such as visible light or heat. However, a photochemical degradation occurs when this excess energy is released, contributing to molecule deterioration. This is evidenced by changes in color and brightness, crack formation, and hardening. ${ }^{27}$

Silicone hardness determines the texture, which must be similar to that of the anatomic site to be restored. $7,26,27,29,41-43$ The skin is very thin in the orbital, nasal, and ear areas of the maxilla, and bone and cartilage are very close to the surface. ${ }^{7,13}$ Thus, in order to mimic the texture of those sites, the silicone should exhibit hardness values of between 25 and 35 Shore A.
In this study, although hardness values increased after aging (Table 2), they decreased after the addition of nanoparticles, sometimes to below the minimum set (25 Shore A). 7,26,27,29,41-43 Nguyen et $\mathrm{al}^{23}$ suggested that the addition of a polyurethane liner could correct the values affected. However, $\mathrm{TiO}_{2}$ was the nanoparticle that had the greater influence on decreasing hardness. In this case, the most likely reason for hardness reduction could be the nature of the nanoparticles. Although $\mathrm{TiO}_{2}$ nanoparticles are very small, allowing them to penetrate between the polymer molecules, they have difficulty dispersing in organic solvents and tend to agglomerate easily. ${ }^{13,14,46}$ The agglomerations can reach micrometric scales larger than the polymer particles, so empty areas may arise around these agglomerations, ${ }^{46}$ which are detrimental to the mechanical properties of the material. Therefore, the surface of this nanoparticle may require modification to reduce its clumping ${ }^{46}$ and improve its dispersion into the silicone matrix.

The hardness values were not influenced by the addition of oil paint, except for the $\mathrm{TiO}_{2} 2 \%$ group (Table 2). This exception may be directly related to higher concentration levels of nanoparticles, which lead to agglomeration formation as explained, and not to the addition of the oil paint itself. Different results regarding oil paint addition can be observed in the literature ${ }^{27}$ when this pigment influenced the initial hardness values. This may be because of the difference in time between the specimen fabrication and test application.

Regarding the tear strength test, higher values were observed after accelerated aging (Table 3). As explained for hardness values, this increase may be due to continuous polymerization of silicone associated with exposure to UV rays. ${ }^{9,18-20,22,23}$ Higher tear strength values for groups with the addition of $\mathrm{BaSO}_{4}$ were observed in the final period. In this study, different nanoparticles were used, which could interact with materials in different ways. Therefore, $\mathrm{BaSO}_{4}$ nanoparticles may have associated more strongly with silicone chains, ${ }^{26}$ increasing tear strength values.

Optimal tear strength values of facial silicone have been stated to be between $0.54 \mathrm{MPa}$ and $1.77 \mathrm{MPa} .^{29,47}$ However, the values obtained in this study, despite being above the maximum recommended value, are clinically satisfactory because a higher tensile strength is more favorable if it does not compromise other properties. Tear strength values, however, are not directly related to hardness values. ${ }^{28}$ The addition of nanoparticles tends to increase the material plasticizing effect, reducing the hardness and increasing the tear strength. ${ }^{24}$ Further tests, such as the elongation test, are needed to confirm these results.

Accelerated aging also influenced permanent deformation (Table 4). Aging increases material rigidity, as seen in the hardness results, resulting in decreased 
permanent deformation values. ${ }^{31,48}$ This effect may be caused by an excessive loss of silicone plasticizer which was not compensated by water absorption, ${ }^{31}$ as shown by Santos et al. ${ }^{27}$

Permanent deformation values were influenced by the addition of $2 \% \mathrm{TiO}_{2}$ nanoparticles after aging (Table 4). This may be associated with nanoparticle agglomeration because of the difficulty in dispersing them among the molecules of the silicone polymer chains. Furthermore, the higher the nanoparticle concentration, the higher the number and size of agglomerations. ${ }^{46}$

The specimens of $1 \% \mathrm{ZnO}$ without oil paint (Supplemental Table 2) showed the lowest values of permanent deformation. This may have occurred because the $\mathrm{ZnO}$ nanoparticles acted as a catalyst ${ }^{15,49}$; this probably caused greater silicone polymerization, increasing hardness, and decreasing permanent deformation. ${ }^{26}$ This can be observed in the current study, in which the highest hardness values were in groups with the $\mathrm{ZnO}$ addition (Table 1).

Some authors ${ }^{32}$ report that permanent deformation values of elastomeric materials above $3 \%$ are not clinically acceptable. The highest permanent deformation value found in this study was $1.33 \%\left(\mathrm{BaSO}_{4} 2 \%\right.$ without adding oil paint). Therefore, all groups proposed in this study are within the acceptable clinical standard.

It was difficult to incorporate and dissolve the nanoparticles homogeneously into the silicone matrix during specimen confection, in particular, the addition of $\mathrm{BaSO}_{4}$ nanoparticles, which may be because of their size (Fig. 2). This can lead to esthetic problems. Thus, future studies could be conducted with the purpose of evaluating and improving their dispersion into the silicone matrix.

\section{CONCLUSIONS}

Despite the limitations of an in vitro study, it was concluded that all tested nanoparticles influenced hardness, tear strength, and permanent deformation values. However, the groups with the $\mathrm{TiO}_{2}$ nanoparticle addition exhibited hardness values lower than the clinically acceptable range, and $\mathrm{BaSO}_{4}$ nanoparticles had the greatest difficulty dispersing in the silicone matrix. Therefore, the use of $\mathrm{ZnO}$ nanoparticles may be a viable method, as they do not negatively affect the material properties evaluated in this study.

\section{REFERENCES}

1. Goiato MC, Pesqueira AA, Ramos da Silva C, Gennari Filho H, Micheline Dos Santos D. Patient satisfaction with maxillofacial prosthesis. Literature review. J Plast Reconstr Aesthet Surg 2009;62:175-80.

2. Kumar S, Rajtilak G, Rajasekar V, Kumar M. Nasal prosthesis for a patient with xeroderma pigmentosum. J Pharm Bioallied Sci 2013;5:176-8.

3. Bangera BS, Guttal SS. Evaluation of varying concentrations of nano-oxides as ultraviolet protective agents when incorporated in maxillofacial silicones: an in vitro study. J Prosthet Dent 2014;112:1567-72.

4. Huber H, Studer SP. Materials and techniques in maxillofacial prosthodontic rehabilitation. Oral Maxillofac Surg Clin North Am 2002;14:73-93.
5. dos Santos DM, Goiato MC, Moreno A, Pesqueira AA, Haddad MF. Influence of pigments and opacifiers on color stability of an artificially aged facial silicone. J Prosthodont 2011;20:205-8.

6. Haddad MF, Goiato MC, Dos Santos DM, Pesqueira AA, Moreno A, Pellizzer EP. Influence of pigment and opacifier on dimensional stability and detail reproduction of maxillofacial silicone elastomer. J Craniofac Surg 2011;22:1612-6

7. Wang L, Liu Q, Jing D, Zhou S, Shao L. Biomechanical properties of nano$\mathrm{TiO}$ addition to a medical silicone elastomer: The effect of artificial ageing. J Dent 2014;42:475-83.

8. Mancuso DN, Goiato MC, Dekon SF, Gennari-Filho H. Visual evaluation of color stability after accelerated aging of pigmented and nonpigmented silicones to be used in facial prostheses. Indian J Dent Res 2009;20:77-80.

9. dos Santos DM, Goiato MC, Sinhoreti MA, Fernandes AU, Ribeiro Pdo P, Dekon SF. Color stability of polymers for facial prosthesis. J Craniofac Surg 2010;21:54-8.

10. Polyzois GL, Eleni PN, Krokida MK. Effect of time passage on some physical properties of silicone maxillofacial elastomers. J Craniofac Surg 2011;22: $1617-21$.

11. Goiato MC, Pesqueira AA, dos Santos DM, Antenucci RM, Ribeiro Pdo P. Evaluation of dimensional change and detail reproduction in silicones for facial prostheses. Acta Odontol Latinoam 2008;21:85-8.

12. Goiato MC, Fernandes AU, dos Santos DM, Barao VA. Positioning magnets on a multiple/sectional maxillofacial prosthesis. J Contemp Dent Pract 2007;8: 101-7.

13. Eleni PN, Katsavou I, Krokida MK, Polyzois GL, Gettleman L. Mechanical behavior of facial prosthetic elastomers after outdoor weathering. Dent Mater 2009:25:1493-502

14. Magdolenova Z, Bilanicova D, Pojana G, Fjellsbo LM, Hudecova A, Hasplova K, et al. Impact of agglomeration and different dispersions of titanium dioxide nanoparticles on the human related in vitro cytotoxicity and genotoxicity. J Environ Monit 2012;14:455-64.

15. Li CH, Liao PL, Shyu MK, Liu CW, Kao CC, Huang SH, et al. Zinc oxide nanoparticles-induced intercellular adhesion molecule 1 expression requires Rac1/Cdc42, mixed lineage kinase 3, and c-Jun N-terminal kinase activation in endothelial cells. Toxicol Sci 2012;126:162-72.

16. Han Y, Zhao Y, Xie C, Powers JM, Kiat-amnuay S. Color stability of pigmented maxillofacial silicone elastomer: effects of nano-oxides as opacifiers. J Dent 2010;38:100-5.

17. Goiato MC, Haddad MF, Pesqueira AA, Moreno A, Dos Santos DM, Bannwart LC. Effect of chemical disinfection and accelerated aging on color stability of maxillofacial silicone with opacifiers. J Prosthodont 2011;20:566-9.

18. Kiat-amnuay S, Beerbower M, Powers JM, Paravina RD. Influence of pigments and opacifiers on color stability of silicone maxillofacial elastomer. J Dent 2009;37:45-50.

19. Kiat-Amnuay S, Lemon JC, Powers JM. Effect of opacifiers on color stability of pigmented maxillofacial silicone A-2186 subjected to artificial aging. J Prosthodont 2002;11:109-16.

20. Kiat-Amnuay S, Mekayarajjananonth T, Powers JM, Chambers MS, Lemon JC. Interactions of pigments and opacifiers on color stability of MDX4-4210/type A maxillofacial elastomers subjected to artificial aging. J Prosthet Dent 2006;95:249-57.

21. Hu X, Pan X, Johnston WM. Effects of pigments on dynamic mechanical properties of a maxillofacial prosthetic elastomer. J Prosthet Dent 2014;112: 1298-303

22. Filie Haddad M, Coelho Goiato M, Micheline Dos Santos D, Moreno A, Filipe D'almeida N, Alves Pesqueira A. Color stability of maxillofacial silicone with nanoparticle pigment and opacifier submitted to disinfection and artificial aging. J Biomed Opt 2011;16:095004.

23. Nguyen CT, Chambers MS, Powers JM, Kiat-Amnuay S. Effect of opacifiers and UV absorbers on pigmented maxillofacial silicone elastomer, part 2: mechanical properties after artificial aging. J Prosthet Dent 2013;109:402-10.

24. Rai SY, Guttal SS. Effect of intrinsic pigmentation on the tear strength and water sorption of two commercially available silicone elastomers. J Indian Prosthodont Soc 2013;13:30-5.

25. Hatamleh MM, Watts DC. Mechanical properties and bonding of maxillofacial silicone elastomers. Dent Mater 2010;26:185-91.

26. Goiato MC, Haddad MF, Santos DM, Pesqueira AA, Moreno A. Hardness evaluation of prosthetic silicones containing opacifiers following chemical disinfection and accelerated aging. Braz Oral Res 2010;24:303-8.

27. dos Santos DM, Goiato MC, Moreno A, Pesqueira AA, Dekon SFdC Guiotti AM. Effect of addition of pigments and opacifier on the hardness, absorption, solubility and surface degradation of facial silicone after artificial ageing. Polym Degrad Stab 2012:97:1249-53.

28. Aziz T, Waters M, Jagger R. Development of a new poly(dimethylsiloxane) maxillofacial prosthetic material. J Biomed Mater Res B Appl Biomater 2003:65:252-61.

29. Lewis DH, Castleberry DJ. An assessment of recent advances in external maxillofacial materials. J Prosthet Dent 1980;43:426-32.

30. Al-Harbi FA, Ayad NM, Saber MA, ArRejaie AS, Morgano SM. Mechanical behavior and color change of facial prosthetic elastomers after 
outdoor weathering in a hot and humid climate. J Prosthet Dent 2014;113:146-51.

31. Takahashi JM, Consani RL, Henriques GE, Nobilo MA, Mesquita MF. Effect of accelerated aging on permanent deformation and tensile bond strength of autopolymerizing soft denture liners. J Prosthodont 2011;20: 200-4.

32. Balkenhol M, Haunschild S, Erbe C, Wostmann B. Influence of prolonged setting time on permanent deformation of elastomeric impression materials. J Prosthet Dent 2010;103:288-94.

33. Koziej D, Fischer F, Kranzlin N, Caseri WR, Niederberger M. Nonaqueous $\mathrm{TiO} 2$ nanoparticle synthesis: a versatile basis for the fabrication of self-supporting, transparent, and UV-absorbing composite films. ACS Appl Mater Interfaces 2009;1:1097-104.

34. Choi SJ, Choy JH. Biokinetics of zinc oxide nanoparticles: toxicokinetics, biological fates, and protein interaction. Int J Nanomedicine 2014:9:261-9.

35. Andreotti AM, Goiato MC, Moreno A, Nobrega AS, Pesqueira AA, Dos Santos DM. Influence of nanoparticles on color stability, microhardness, and flexural strength of acrylic resins specific for ocular prosthesis. Int J Nanomedicine 2014;9:5779-87.

36. Goiato MC, Haddad MF, Sinhoreti MA, dos Santos DM, Pesqueira AA, Moreno A. Influence of opacifiers on dimensional stability and detail reproduction of maxillofacial silicone elastomer. Biomed Eng Online 2010; 9:85.

37. Mancuso DN, Goiato MC, Zuccolotti BC, Moreno A, dos Santos DM, Pesqueira AA. Effect of thermocycling on hardness, absorption, solubility and colour change of soft liners. Gerodontology 2012;29:215-9.

38. American Society for Testing Materials. ASTM D1938-67(1978), standard test method for tear-propagation resistance (trouser tear) of plastic film and thin sheeting by a single-tear method. West Conshohocken, PA: ASTM International; 1978.

39. International Organization for Standardization. ISO- 4823:2000. Dentistry elastomeric impression materials. Geneva: ISO; 2000.

40. American Society for Testing Materials. ASTM D2240-05(2010), Standard test method for rubber property-durometer hardness. West Conshohocken, PA ASTM International; 2010.

41. Guiotti AM, Goiato MC, dos Santos DM. Evaluation of the Shore A hardness of silicone for facial prosthesis as to the effect of storage period and chemical disinfection. J Craniofac Surg 2010;21:323-7.
42. Goiato MC, Pesqueira AA, Santos DM, Dekon SF. Evaluation of hardness and surface roughness of two maxillofacial silicones following disinfection. Braz Oral Res 2009;23:49-53.

43. Goiato MC, Pesqueira AA, Moreno A, dos Santos DM, Haddad MF, Bannwart LC. Effects of pigment, disinfection, and accelerated aging on the hardness and deterioration of a facial silicone elastomer. Polym Degrad Stab 2012;97:1577-80.

44. Goiato MC, Ribeiro PdP, dos Santos DM, Fernandes AÚR, dos Santos PH, Pellizzer EP. Evaluation of elastic recovery and tear strength of a silicone for use in facial prosthesis under the influence of pigmentation and chemical disinfection. Rev Odontol UNESP 2004;33:189-94. [in Portuguese].

45. American Society for Testing Materials. ASTM G53-96, practice for operating light- and water-exposure apparatus (fluorescent UV-condensation type) for exposure of nonmetallic materials (withdrawn 2000). West Conshohocken, PA: ASTM International; 1996. Avaiable at: http://www.astm.org/Standards/ G53. Accessed January 20, 2014.

46. Xia Y, Zhang F, Xie H, Gu N. Nanoparticle-reinforced resin-based dental composites. J Dent 2008;36:450-5.

47. May PD. Maxillofacial prostheses of chlorinated polyethylene. J Biomed Mater Res 1978;12:421-31.

48. Duran RL, Powers JM, Craig RG. Viscoelastic and dynamic properties of soft liners and tissue conditioners. J Dent Res 1979;58:1801-7.

49. Osmond G, Boon JJ, Puskar L, Drennan J. Metal stearate distributions in modern artists' oil paints: surface and cross-sectional investigation of reference paint films using conventional and synchrotron infrared microspectroscopy. Appl Spectrosc 2012;66:1136-44.

\section{Corresponding author:}

Dr Marcelo Coelho Goiato

Aracatuba Dental School (UNESP)

Department of Dental Materials and Prosthodontics

José Bonifácio, 1193 - Vila Mendonça

Araçatuba, SP

BRAZIL

Email: goiato@foa.unesp.br

Copyright (C) 2016 by the Editorial Council for The Journal of Prosthetic Dentistry.

\section{Availability of Journal Back Issues}

As a service to our subscribers, copies of back issues of The Journal of Prosthetic Dentistry for the preceding 5 years are maintained and are available for purchase from Elsevier, Inc until inventory is depleted. Please write to Elsevier, Inc, Subscription Customer Service, 6277 Sea Harbor Dr, Orlando, FL 32887, or call 800-654-2452 or 407-345-4000 for information on availability of particular issues and prices. 
Supplemental Table 1. Results of nested ANOVA for hardness (Shore A)

\begin{tabular}{|c|c|c|c|c|c|c|}
\hline Source & $d f$ & SS & SS & MS & $\mathbf{F}$ & $\boldsymbol{P}$ \\
\hline Oil paint & 1 & 173.38 & 124.82 & 124.82 & 52.92 & $<.001 *$ \\
\hline Concentration & 2 & 990.58 & 990.58 & 495.29 & 209.98 & $<.001^{*}$ \\
\hline Nanoparticle concentration & 4 & 947.02 & 947.02 & 236.76 & 100.37 & $<.001^{*}$ \\
\hline Period & 1 & 1313.00 & 968.59 & 968.59 & 410.63 & $<.001^{*}$ \\
\hline Oil paint $\times$ concentration & 2 & 9.36 & 9.36 & 4.68 & 1.98 & .140 \\
\hline $\begin{array}{l}\text { Oil paint } \times \text { nanoparticle } \\
\text { concentration }\end{array}$ & 4 & 225.99 & 225.99 & 56.50 & 23.95 & $<.001^{*}$ \\
\hline Oil paint $\times$ period & 1 & 0.21 & 2.62 & 2.62 & 1.11 & .293 \\
\hline Period $\times$ concentration & 2 & 61.83 & 61.83 & 30.92 & 13.11 & $<.001^{*}$ \\
\hline $\begin{array}{l}\text { Period } \times \text { nanoparticle } \\
\text { concentration }\end{array}$ & 4 & 33.08 & 33.08 & 8.27 & 3.51 & $.008^{*}$ \\
\hline Oil paint $\times$ concentration $\times$ period & 2 & 11.20 & 11.20 & 5.60 & 2.37 & .095 \\
\hline $\begin{array}{l}\text { Oil paint } \times \text { nanoparticle } \\
\text { concentration } \times \text { period }\end{array}$ & 4 & 31.12 & 31.12 & 7.78 & 3.30 & $.012^{*}$ \\
\hline Error & 252 & 594.41 & 594.41 & 2.36 & & \\
\hline Total & 279 & 4391.20 & & & & \\
\hline
\end{tabular}

$d f$, degrees of freedom; MS, mean of squares; $\mathrm{SS}$, sum of squares. ${ }^{*} P<.05$, statistically sig nificant difference.

Supplemental Table 2. Results of nested ANOVA for tear strength (MPa)

\begin{tabular}{|c|c|c|c|c|c|c|}
\hline Source & $d f$ & SS & SS & MS & $\mathbf{F}$ & $\boldsymbol{P}$ \\
\hline Oil paint & 1 & 0.22 & 0.02 & 0.02 & 0.10 & .755 \\
\hline Concentration & 2 & 0.56 & 0.56 & 0.28 & 1.24 & .290 \\
\hline Nanoparticle concentration & 4 & 6.61 & 6.61 & 1.65 & 7.36 & $<.001^{*}$ \\
\hline Period & 1 & 15.79 & 13.40 & 13.40 & 59.63 & $<.001^{*}$ \\
\hline Oil paint $\times$ concentration & 2 & 1.44 & 1.44 & 0.72 & 3.20 & $.042^{*}$ \\
\hline $\begin{array}{l}\text { Oil paint } \times \text { nanoparticle } \\
\text { concentration }\end{array}$ & 4 & 4.98 & 4.98 & 1.25 & 5.54 & $<.001^{*}$ \\
\hline Oil paint×period & 1 & 1.03 & 0.03 & 0.03 & 0.11 & .735 \\
\hline Period $\times$ concentration & 2 & 2.33 & 2.33 & 1.16 & 5.18 & $.006 *$ \\
\hline $\begin{array}{l}\text { Period } \times \text { nanoparticle } \\
\text { concentration }\end{array}$ & 4 & 1.73 & 1.73 & 0.43 & 2.93 & $.022^{*}$ \\
\hline Oil paint $\times$ concentration $\times$ period & 2 & 2.38 & 2.38 & 1.19 & 5.30 & $.006^{*}$ \\
\hline $\begin{array}{l}\text { Oil paint } \times \text { nanoparticle } \\
\text { concentration } \times \text { period }\end{array}$ & 4 & 2.63 & 2.63 & 0.66 & 1.93 & .106 \\
\hline Error & 252 & 56.63 & 56.63 & 0.22 & & \\
\hline Total & 279 & 96.35 & & & & \\
\hline
\end{tabular}

$d f$, degrees of freedom; MS, mean of squares; $\mathrm{SS}$, sum of squares. ${ }^{*} P<.05$, statistically sig nificant difference.
Supplemental Table 3. Results of nested ANOVA for permanent deformation (\%)

\begin{tabular}{|c|c|c|c|c|c|c|}
\hline Source & $d f$ & SS & SS & MS & $\mathbf{F}$ & $P$ \\
\hline Oil paint & 1 & 0.108 & 0.135 & 0.135 & 4.54 & $.034^{*}$ \\
\hline Concentration & 2 & 0.680 & 0.680 & 0.340 & 11.43 & $<.001^{*}$ \\
\hline Nanoparticle concentration & 4 & 1.822 & 1.822 & 0.455 & 15.33 & $<.001^{*}$ \\
\hline Period & 1 & 1.457 & 1.335 & 1.335 & 44.92 & $<.001^{*}$ \\
\hline Oil paint $\times$ concentration & 2 & 0.146 & 0.146 & 0.073 & 2.46 & .087 \\
\hline $\begin{array}{l}\text { Oil paint } \times \text { nanoparticle } \\
\text { concentration }\end{array}$ & 4 & 0.309 & 0.309 & 0.077 & 2.60 & $.037^{*}$ \\
\hline Oil paint $\times$ Period & 1 & 0.037 & 0.010 & 0.010 & 0.35 & .554 \\
\hline Period×concentration & 2 & 0.717 & 0.717 & 0.358 & 12.06 & $<.001^{*}$ \\
\hline Period×nanoparticle concentration & 4 & 3.760 & 3.760 & 0.940 & 31.63 & $<.001^{*}$ \\
\hline Oil paint Xconcentration $\times$ period & 2 & 0.053 & 0.053 & 0.026 & 0.89 & .412 \\
\hline $\begin{array}{l}\text { Oil paint } \times \text { nanoparticle } \\
\text { concentration } \times \text { period }\end{array}$ & 4 & 0.196 & 0.196 & 0.049 & 1.65 & .163 \\
\hline Error & 252 & 7.489 & 7.489 & 0.030 & & \\
\hline Total & 279 & 16.773 & & & & \\
\hline
\end{tabular}

$d f$, degrees of freedom; MS, mean of squares; SS, sum of squares. ${ }^{*} P<.05$, statistically significant difference. 